\title{
PRODUKSI DAN KARAKTERISASI XILANASE DARI ISOLAT BAKTERI M-13.2A ASAL AIR LAUT MANADO
}

\section{Production and Characterization of Xilanase Produced by Bacteria M-13.2A Isolate from Manado Seawater}

\author{
Yusro Nuri Fawzya ${ }^{1 *}$, Rani Elsa Prima ${ }^{2}$, Wibowo Mangunwardoyo ${ }^{2}$ \\ Ifah Munifah ${ }^{1}$ dan Gintung Patantis ${ }^{1}$ \\ ${ }^{1}$ Balai Besar Penelitian dan Pengembangan Pengolahan Produk dan Bioteknologi Kelautan dan Perikanan, KKP. \\ JI. K.S. Tubun Petamburan VI, Jakata Pusat 10260 \\ 2 Program Studi Biologi, FMIPA-UI \\ * Korespondensi Penulis: nuri_fawzya@yahoo.com \\ Diterima: 21 Agustus 2012, Disetujui: 13 Maret 2013
}

\begin{abstract}
ABSTRAK
Isolat bakteri M-13.2A yang berasal dari laut Manado diketahui mampu menghasilkan enzim selulase dan xilanase, berdasarkan pembentukan zona bening pada media padat. Penelitian ini bertujuan untuk mendapatkan informasi lebih lanjut mengenai produksi dan sifat enzim xilanase yang dihasilkan dari isolat bakteri M-13.2A serta identifikasi isolat bakteri tersebut di atas. Sebanyak $(2,4-3,3) \times 10^{8} \mathrm{cfu} / \mathrm{ml}$ inokulum dengan konsentrasi sekitar $9 \%(\mathrm{v} / \mathrm{v})$ diinokulasikan dalam medium xylan broth, kemudian diinkubasi selama 6 hari pada suhu $30^{\circ} \mathrm{C}, 150 \mathrm{rpm}$. Pengambilan sampel dilakukan setiap hari dan enzim yang dihasilkan diuji aktivitasnya dengan metode asam dinitro salisilat (DNS). Hasil penelitian menunjukkan bahwa aktivitas xilanase tertinggi dihasilkan pada hari ke-2 inkubasi, sebesar 5,17 U/ml. Enzim xilanase ini bekerja optimum pada $\mathrm{pH}$ 8, suhu $70^{\circ} \mathrm{C}$. Penambahan ion logam $10 \mathrm{mM}$ memberikan pengaruh yang bervariasi terhadap aktivitas enzim. Ion $\mathrm{Zn}^{2+}$ meningkatkan aktivitas xilanase hingga $278,1 \%$. Ion $\mathrm{Fe}^{3+}$ dan $\mathrm{Ca}^{2+}$ menurunkan aktivitas xilanase menjadi 75 dan $8,3 \%$ relatif terhadap kontrol, sedangkan ion $\mathrm{K}^{+}$tidak memberikan pengaruh terhadap aktivitas xilanase. Hasil identifikasi bakteri menunjukkan bahwa isolat M13.2A memiliki kemiripan 99\% dengan Acinetobacter baumannii.
\end{abstract}

KATAKUNCl: $\quad$ isolate bakteri M-13.2A, identifikasi, xilanase, produksi, karakterisasi

\section{ABSTRACT}

Bacteria isolate designated as M-13.2A from Manado seawater was able to produce cellulase as well as xilanase, based on clear zone formed on specific solid media. This research was intended to obtain further information about production and characterization of xilanase produced by the isolate as well as identification of the M-13.2A isolate. Inoculum with the amount of (2.4-3.3) $\times 10^{8} \mathrm{cfu} / \mathrm{ml}$ and $9 \%(\mathrm{~V} / \mathrm{V})$ concentration was inoculated into xylan broth, then incubated for 6 days at the temperature of $30^{\circ} \mathrm{C}, 150 \mathrm{rpm}$. Sampling was carried out every day and the enzyme produced was assayed their activity using the dinitrosalicylic acid (DNS) method. The result showed that the highest xilanase activity was produced from 2 days fermentation, i.e. $5.17 \mathrm{U} / \mathrm{ml}$. This enzyme worked optimally at the $\mathrm{pH}$ of 8 , temperature of $70^{\circ} \mathrm{C}$. Addition of $10 \mathrm{mM}$ metal ions gave various effect on the enzyme activity. Ions $\mathrm{Zn}^{2+}$ increased the activity up to $278.1 \%$. Ions $\mathrm{Fe}^{3+}$ and $\mathrm{Ca}^{2+}$ inhibited the activity, resulting the activity of $75 \%$ and $8.3 \%$ relative to control, while ion $\mathrm{K}^{+}$did not affect the xilanase activity. Based on molecular identification, the $M-13.2 \mathrm{~A}$ isolate was $99 \%$ similar to Acinetobacter baumannii.

KEYWORDS: $\quad$ bacteria M-13.2A isolate, identification, xilanase, production, characterization

\section{PENDAHULUAN}

Eksplorasi enzim mikroba, termasuk dari mikroba laut, masih banyak diminati terkait dengan tingginya kebutuhan enzim yang cenderung mengalami peningkatan dari tahun ke tahun. Menurut kajian BCC
(2011), pasar global untuk enzim-enzim industri pada tahun 2010 diperkirakan mencapai nilai \$3,3 triliun dan akan meningkat pada tahun 2015 dengan nilai diperkirakan mencapai $\$ 4,4$ triliun dan tingkat pertumbuhan tahunan gabungan atau compound annual growth rate (CAGR) sebesar $6 \%$. Sementara 
itu berdasarkan hasil studi dari grup Freedonia (2011), sampai dengan tahun 2015 peningkatan permintaan enzim diperkirakan sekitar 6,3\% rata-rata per tahun dengan nilai mencapai $\$ 7,6$ triliun. Di antara berbagai jenis enzim tersebut, enzim-enzim karbohidrase mengalami peningkatan cukup tinggi setelah enzimenzim untuk farmasi, diagnostik/bioteknologi dan enzim lipase. Hal ini berhubungan dengan aplikasi yang sangat luas dari enzim-enzim karbohidrase tersebut (Freedonia, 2011). Tingginya permintaan akan enzim tersebut antara lain dikarenakan pemanfaatan enzim yang sangat luas dan dapat meningkatkan efisiensi proses produksi serta sifatnya yang spesifik dan ramah lingkungan .

Xilanase (EC 3.2.1.8) merupakan enzim yang berperan dalam hidrolisis xilan (hemiselulosa) menjadi xilo-oligosakarida dan xilosa. Aplikasi enzim ini cukup luas, di antaranya digunakan pada industri pulp dalam proses deinking dan bleaching sebagai pengganti proses kimiawi, yaitu penggunaan klorin yang bersifat toksik. Pada industri makanan dan minuman, xilanase digunakan untuk meningkatkan daya kembang roti, meningkatkan tekstur dan keseragaman wafer, menghasilkan gula rendah kalori untuk membantu diet penderita diabetes mellitus, dan sebagai bahan penjernih dalam industri minuman/jus buah. Pada industri farmasi, xilanase digunakan sebagai salah satu jenis enzim pada formula sediaan suplemen untuk mengatasi masalah pencernaan dan menghambat terjadinya osteoporosis, serta sebagai bahan tambahan pada formula pasta gigi. Xilanase juga dapat digunakan pada industri pakan ternak, bersama-sama dengan enzim-enzim lainnya seperti glukanase, pektinase, selulase, lipase dan lain-lain serta berpotensi membantu dalam pra-perlakuan biomassa pada industri bioenergi (Richana, 2002, Polizeli et al., 2005; Degue, 2013)

Enzim xilanase dapat dihasilkan oleh berbagai jenis bakteri, khamir, kapang, protozoa, serangga dan siput. Eksplorasi xilanase bakteri telah banyak dilaporkan, di antaranya adalah xilanase dari bakteri laut Vibrio sp. XY-214 (Araki et al., 1999), dari Bacillus subtilis (Annamalai et al., 2009), dan dari Thermoanaerobacterium saccharolyticum NTOU1 (Hung et al., 2011). Balai Besar Penelitian dan Pengembangan Pengolahan Produk dan Bioteknologi Kelautan dan Perikanan memiliki koleksi isolat bakteri penghasil enzim potensial, salah satunya isolat bakteri laut M-13.2A dari perairan Manado, yang diketahui mempunyai kemampuan menghasilkan enzim xilanase dengan indeks xilanolitik yang tinggi, yaitu 20 (Munifah et al., 2009). Penelitian ini dimaksudkan untuk mendapatkan informasi lebih lanjut mengenai identitas isolat M-13.2A dan karakter enzim xilanase yang dihasilkan.

\section{BAHAN DAN METODE}

\section{Bahan}

Isolat bakteri M-13.2A yang digunakan pada penelitian ini merupakan salah satu koleksi isolat Laboratorium Bioteknologi, Balai Besar Penelitian dan Pengembangan Pengolahan produk dan Bioteknologi Kelautan dan Perikanan. Bakteri ini diisolasi dari perairan Manado dan mampu menghidrolisis substrat yang mengandung xilan (Munifah et al., 2009). Bahanbahan untuk identifikasi isolat bakteri, di antaranya adalah kristal violet, safranin, lugols iodine, hidrogen peroksida, serta bahan-bahan untuk ekstraksi, purifikasi dan sekuensing DNA. Selain itu, bahan lain yang digunakan meliputi bahan untuk medium produksi xilanase, seperti xilan beechwood, ekstrak khamir, polipepton serta bahan kimia lainnya untuk pengujian aktivitas enzim dan karakterisasi xilanase.

\section{Metode}

\section{Penyegaran isolat dan identifikasi bakteri}

Isolat bakteri yang tersimpan dalam sediaan liofillisasi disegarkan terlebih dahulu dalam medium NB selama 24 jam. Terhadap isolat bakteri yang telah tumbuh kemudian dilakukan inokulasi dengan metode streak pada medium NA miring sebagai stock culture dan pada cawan petri berisi medium NA sebagai working culture.

Identifikasi bakteri dilakukan baik secara biokimia maupun secara molekuler. Identifikasi secara biokimia dilakukan melalui pengamatan morfologi bakteri secara makroskopik dan mikroskopik, dilanjutkan dengan pengamatan aktivitas biokimia yaitu aktivitas katalase dan oksidase. Sedangkan identifikasi secara molekuler dilakukan berdasarkan analisis sekuen 16S-rDNA.

Pengamatan morfologi bakteri secara makroskopik meliputi bentuk koloni, permukaan koloni, dan warna koloni, dilakukan menurut metode Gandjar et al., 1992). Sedangkan pengamatan mikroskopik dilakukan melalui pewarnaan Gram berdasarkan metode Benson (2001). Uji aktivitas biokimia dilakukan melalui pengujian katalase (Ganjar et al., 1992) dan uji oksidase dengan menggunakan oksidase strip.

Identifikasi bakteri berdasarkan analisis sekuen 16S-rDNA, diawali dengan ekstraksi dan purifikasi DNA menggunakan Genomic DNA Purification Kit (Fermentas). Amplifikasi DNA dilakukan dengan primer 16S rDNA-63F dan 16S rDNA-1387R (Marchesi et al., 1998) menggunakan Pure Taq Ready To Go PCR beads (GE Healthcare). DNA yang diperoleh kemudian disekuen di First Laboratory, Singapura. Sekuen nukleotida yang dihasilkan kemudian dianalisis 
menggunakan program Clustal $W$ yang tersedia pada situs European Bioinformatic Institute. Pembuatan pohon filogenetik dilakukan dengan menggunakan program Treecon 1.3b.

\section{Produksi enzim dan uji aktivitas enzim xilanase}

Produksi enzim didahului dengan pembuatan starter dengan cara menginokulasikan kultur segar bakteri ke dalam medium starter (xylan broth), diinkubasi pada suhu $30^{\circ} \mathrm{C}, 150 \mathrm{rpm}$. Lama waktu inkubasi untuk memindahkan starter ke dalam medium produksi enzim ditentukan berdasarkan waktu di mana starter mengalami pertumbuhan yang cepat atau dalam fase logaritmik, yang diketahui dari kurva pertumbuhan. Untuk membuat kurva pertumbuhan, terhadap starter dilakukan pengukuran absorbansi pada $\lambda=600 \mathrm{~nm}\left(\mathrm{OD}_{60}\right)$ setiap 3 jam sampai dengan 40 jam. Biasanya nilai $\mathrm{OD}_{600}$ sebesar 0,6-0,8 dianggap cukup untuk memindahkan starter ke dalam medium produksi (Saleem et al., 2009). Untuk mengetahui berapa banyak jumlah sel yang dimasukkan ke dalam medium produksi enzim, dilakukan pengujian total plate count menggunakan metode sebar (spread) pada medium Nutrient Agar.

Starter sebanyak 10\% dimasukkan ke dalam medium produksi (xylan broth) yang mengandung $1 \%$ polipepton, $0,5 \%$ yeast extract, $0,1 \% \mathrm{KH}_{2} \mathrm{PO}_{4}, 0,02 \%$ $\mathrm{MgSO}_{4 \cdot 7} \mathrm{H}_{2} \mathrm{O}, 1 \% \mathrm{Na}_{2} \mathrm{CO}_{3}, 0,5 \%$ beechwood xylan (Sigma) dan $0,3 \% \mathrm{NaCl}$ dalam akuades, dan diatur pHnya menjadi 9,0 menggunakan $\mathrm{NaOH} 0,1 \mathrm{~N}$ (Annamalai et al., 2009). Kultur diinkubasi pada suhu $30^{\circ} \mathrm{C}, 150 \mathrm{rpm}$ selama 5 hari dan setiap hari dilakukan pengambilan sampel untuk diukur $\mathrm{OD}_{600}$ dan aktivitas enzimnya. Enzim kasar diperoleh dari supernatant hasil sentrifugasi kultur pada kecepatan 10.000 rpm, suhu $4^{\circ} \mathrm{C}$, selama 15 menit. Enzim kasar selanjutkan diuji aktivitasnya dengan metode DNS menurut Biely (2003), menggunakan kurva standar xilosa. Satu unit aktivitas xilanase merupakan jumlah enzim yang dibutuhkan untuk memecah xilan menjadi $1 \mu \mathrm{mol}$ gula pereduksi per menit pada kondisi pengujian.

\section{Karakterisasi enzim}

Karakterisasi enzim dilakukan untuk menentukan $\mathrm{pH}$ dan suhu optimum serta pengaruh ion logam terhadap aktivitas enzim. pH optimum ditentukan dengan cara mengukur aktivitas enzim pada berbagai $\mathrm{pH}$ (buffer $\mathrm{pH}$ 4-10), suhu optimum ditentukan dengan melakukan pengujian aktivitas enzim pada suhu 40$90^{\circ} \mathrm{C}$ dengan interval suhu $10^{\circ} \mathrm{C}$, sedangkan ion logam yang dilihat pengaruhnya adalah ion $\mathrm{Ca}^{2+}, \mathrm{Mg}^{2+}, \mathrm{Zn}^{2+}$, dan $\mathrm{Fe}^{3+}$ dalam bentuk garam klorida.

\section{HASIL DAN BAHASAN}

\section{Identifikasi Bakteri}

Identifikasi bakteri telah dilakukan berdasarkan analisis fenotip maupun genotipnya. Analisis fenotip dilakukan melalui pengamatan ciri-ciri morfologi bakteri, sedangkan analisis genotip dilakukan dengan teknik molekuler. Prinsip identifikasi bakteri secara molekuler adalah membandingkan sekuen DNA sampel dengan sekuen yang terdapat dalam database.

Hasil pengamatan morfologi isolat bakteri M-13.2A secara makroskopik maupun pewarnaan Gram yang menunjukkan morfologi secara mikroskopik serta aktivitas biokimianya disajikan pada Tabel 1 ,

Tabel 1. Hasil pengamatan morfologi makroskopik, mikroskopik dan uji aktivitas biokimia isolat bakteri M13.2A umur 24 jam pada medium NA

Table 1. Macro- and microscopic morphology of M-13.2A isolate at NA medium for $24 \mathrm{~h}$ incubation

\begin{tabular}{|c|c|}
\hline Pengamatan/Observation & Keterangan/Description \\
\hline \multicolumn{2}{|c|}{ 1. Morfologi mikroskopik/Microscopic morphology: } \\
\hline Bentuk sel/Cell shape & Batang pendek hampir bulat/coccobacilli \\
\hline Gram & Gram negatif/Gram negative \\
\hline \multicolumn{2}{|c|}{ 2. Morfologi makroskopik/Macroscopic morphology: } \\
\hline Ukuran koloni/Colony size & $1,2--1,8 \mathrm{~mm}$ \\
\hline Bentuk koloni/Colony shape & Bulat/Round \\
\hline Tepi koloni/Colony edge & Tidak rata/Undulate \\
\hline Warna koloni/Colony colour & Putih susu/White \\
\hline Elevasi koloni/Colony elevation & Cembung/Convex \\
\hline \multicolumn{2}{|c|}{ 3. Uji aktivitas biokimia/Biochemical activity test: } \\
\hline Katalase/Catalase & Positif/Positive \\
\hline Oksidase/Oxidase & Negatif/Negative \\
\hline
\end{tabular}


Gambar 1 dan Gambar 2. Hasil identifikasi bakteri secara molekuler disajikan dalam bentuk pohon filogenetik (Gambar 3). Berdasarkan hasil pengamatan morfologi secara makroskopik dan mikroskopik serta uji aktivitas biokimia dan dicocokkan dengan Bergey's Manual of Determinative Bacteriology (Holt et al., 1994), isolat tersebut termasuk dalam genus Acinetobacter. Sedangkan hasil identifikasi secara molekuler menunjukkan bahwa isolat bakteri M-13.2A berkerabat sangat dekat dengan Acinetobacter baumannii (Gambar 3), dengan tingkat kemiripan 99\% yang diperoleh dari hasil analisis sekuen menggunakan basic local alignment search tool (BLAST). Dengan demikian dapat disimpulkan bahwa isolat ini adalah Acinetobacter baumannii M-13.2A.

Acinetobacter baumannii merupakan bakteri Gram negatif, berbentuk coccobacilli, dengan koloni berdiameter 2-3 mm pada umur 18-24 jam. Selain itu bakteri ini bersifat katalase positif dan oksidase negatif (Constantiniu et al., 2004). Sedangkan menurut Bouvet \& Grimont (1987) bakteri ini mampu tumbuh pada suhu $44^{\circ} \mathrm{C}$ sehingga dapat dibedakan dari $A$. calcoaceticus dan spesies Acinetobacter yang lain.

Bakteri ini bersifat pathogen (Bergogne-Berezin \& Towner, 1996; Constantiniu et al., 2004; Peleg et al., 2008) namun jenis bakteri ini yang diisolasi dari spons Plakortis nigra dilaporkan menghasilkan inhibitor yang menghambat protease yang dihasilkan oleh Escherichia coli (Nurhayati et al., 2006). Pada E.coli dan beberapa jenis bakteri lainnya, protease merupakan salah satu faktor virulensi yang menyebabkan terjadinya infeksi dan penyakit ketika berinteraksi dengan komponen inang (Retnoningrum, 2009). Dengan kemampuannya menghasilkan inhibitor protease E.coli, maka A.baumannii juga berpotensi digunakan untuk menanggulangi penyakit yang mekanisme penyebarannya melalui faktor virulensi (protease) tersebut.

\section{Penentuan waktu produksi enzim}

Kultur bakteri yang diinokulasikan pada medium produksi enzim, biasa disebut starter, umumnya
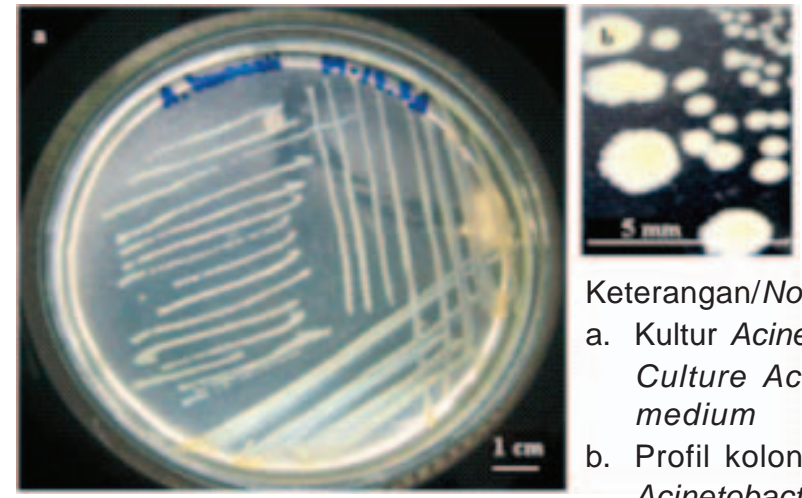

Keterangan/Note:

a. Kultur Acinetobacter baumannii M-13.2A pada medium NA/ Culture Acinetobacter baumannii M-13.2A isolate on NA medium

b. Profil koloni Acinetobacter baumannii M-13.2A/Coloni profil Acinetobacter baumannii M-13.2A

Gambar 1. Pengamatan makroskopik isolat bakteri M-13.2A pada medium NA, umur 24 jam, suhu $37^{\circ} \mathrm{C}$. Figure 1. Macroscopic morphology of M-13.2A isolate on NA medium at $37^{\circ} \mathrm{C}, 24 \mathrm{~h}$.

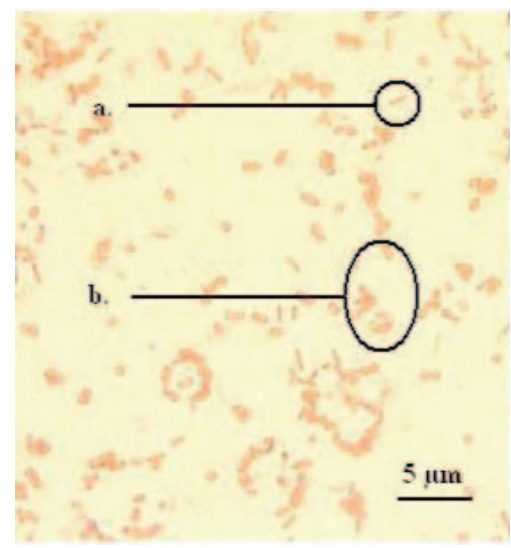

Keterangan/Note:

a. Bentuk sel cocobasil/Cell shape cocobacil

b. Warna merah menunjukkan Gram negatif/ Red colour showed Gram negative

Gambar 2. Hasil pewarnaan Gram isolat bakteri M-13.2A dari medium NA, umur 24 jam, suhu $37^{\circ} \mathrm{C}$.

Figure 2. Result of Gram staining of M-13.2A isolate from NA medium at $37^{\circ} \mathrm{C}, 24 \mathrm{~h}$. 


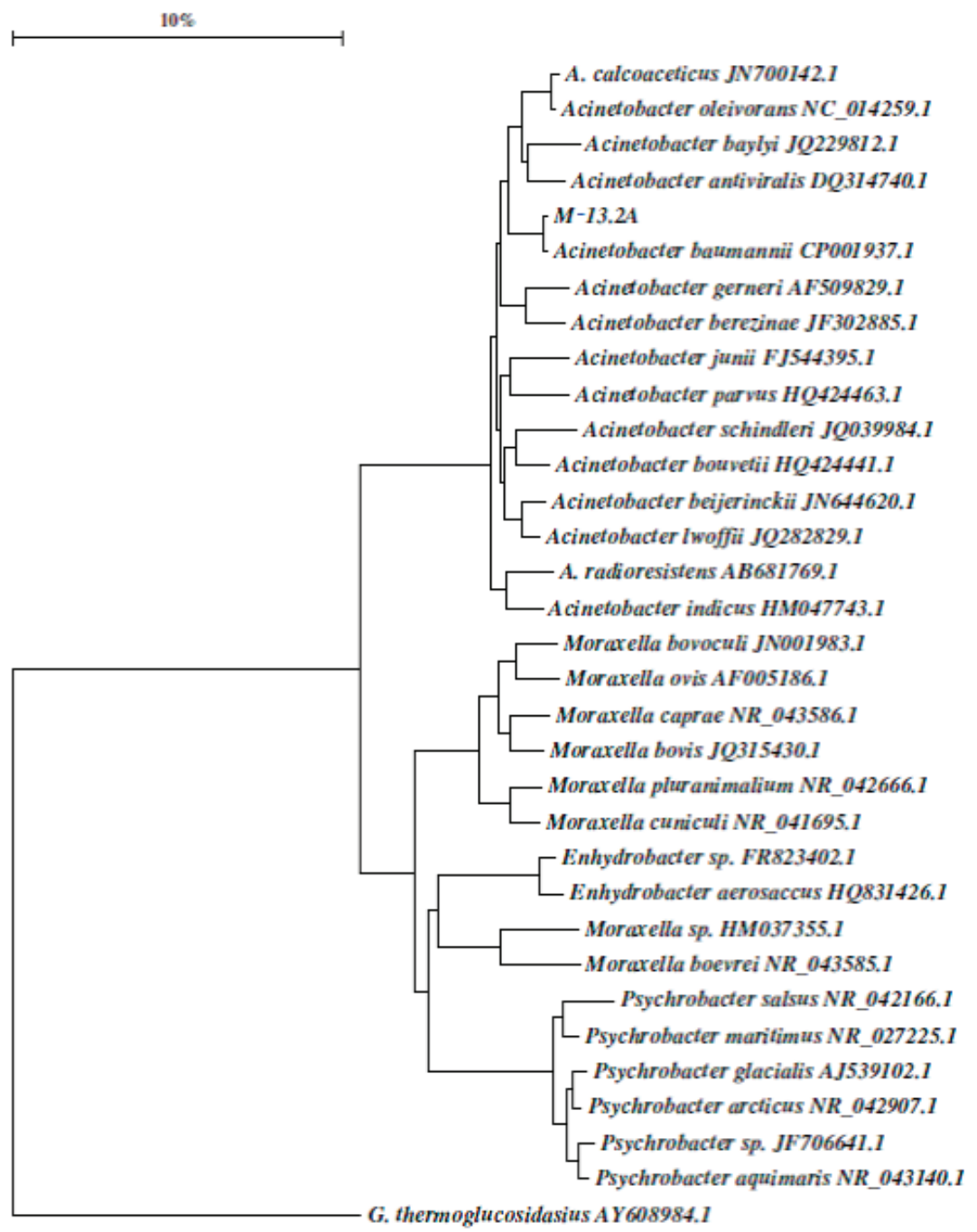

Gambar 3. Pohon filogenetik isolat bakteri M-13.2A

Figure 3. Phylogenetic tree of isolate $M-13.2 A$

adalah kultur bakteri yang sedang mengalami pertumbuhan dengan nilai OD ${ }_{600} 0,6-0,8$ (Saleem et al., 2009). Annamalai et al. (2009) melaporkan penggunaan inokulum Bacillus subtilis dengan kepadatan sel 1,85 × $10^{6} \mathrm{cfu} / \mathrm{ml}$ dalam fermentasi untuk produksi xilanase. Pada penelitian ini kurva pertumbuhan starter terlihat landai (Gambar 4) memberikan gambaran bahwa fase log berlangsung pada kisaran waktu yang cukup lama (sekitar 2-12 jam). Namun berdasarkan acuan di atas dan pengamatan terhadap kurva pertumbuhan, inkubasi starter selama 6 jam yang menghasilkan nilai $O_{600}$ 0,715 dengan total bakteri $(2,4-3,3) \times 10^{8} \mathrm{cfu} / \mathrm{ml}$ diperkirakan telah memadai untuk dipindahkan ke dalam medium produksi.

Pertumbuhan $A$. baumannii M-13.2A pada medium produksi mengikuti pola kurva pertumbuhan yang normal dengan fase logaritme terjadi sampai hari ke-2 (Gambar 4). Aktivitas enzim sudah mulai terdeteksi sejak awal inkubasi, hal ini diduga berasal dari starter yang ditambahkan pada medium produksi yang berada pada fase log dan telah menghasilkan enzim ekstraseluler. Menurut Brock et al. (1994) enzim ekstraseluler telah dihasilkan pada fase log dan akan terakumulasi pada fase stasioner. Aktivitas enzim xilanase mencapai maksimum pada hari ke-2, dimana kecepatan pertumbuhan mulai berkurang. Dengan demikian waktu optimum untuk produksi xilanase dari A.baumannii M-13.2A berdasarkan metode ini adalah 2 hari. Waktu panen enzim ini relatif singkat. Beberapa enzim xilanase mikroba dilaporkan mempunyai waktu produksi 4-7 hari seperti xilanase dari Bacillus subtilis cho40 yang membutuhkan waktu 4 hari (Khandeparker et al., 2011), xilanase dari Chaetomium sp. yang memerlukan waktu 6 hari (Jiang et al., 2010) dan xilanase dari Streptomyces rameus L2001 yang dipanen setelah 7 hari inkubasi (Li et al., 2010). 


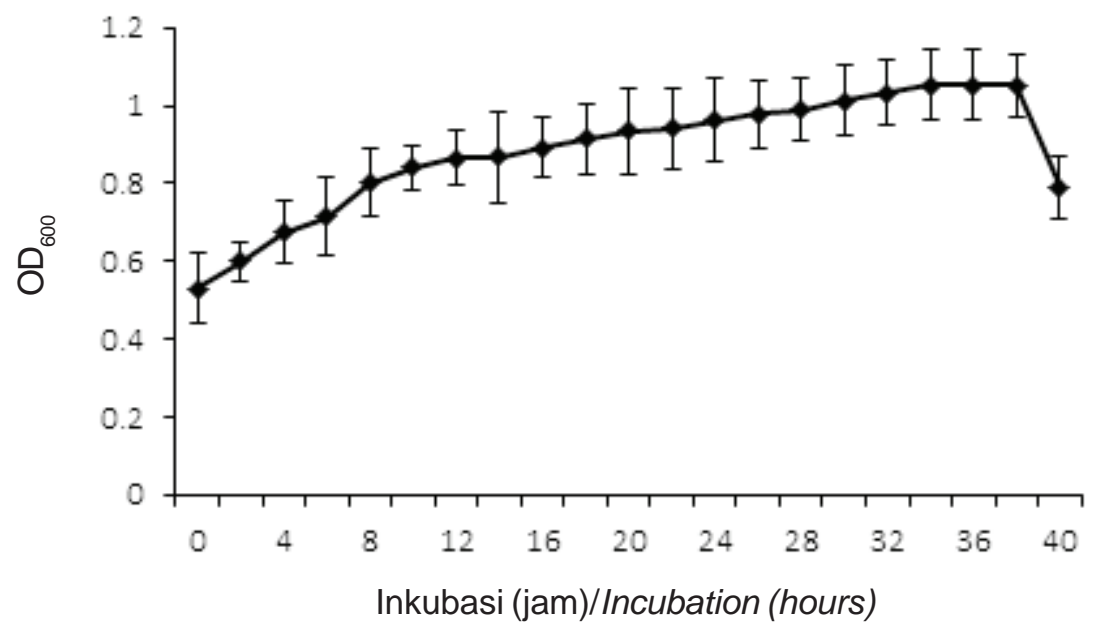

Gambar 4. Kurva pertumbuhan A. baumannii M-13.2A sebagai starter.

Figure 4. Growth curve of $A$. baumannii M-13.2A as starter.

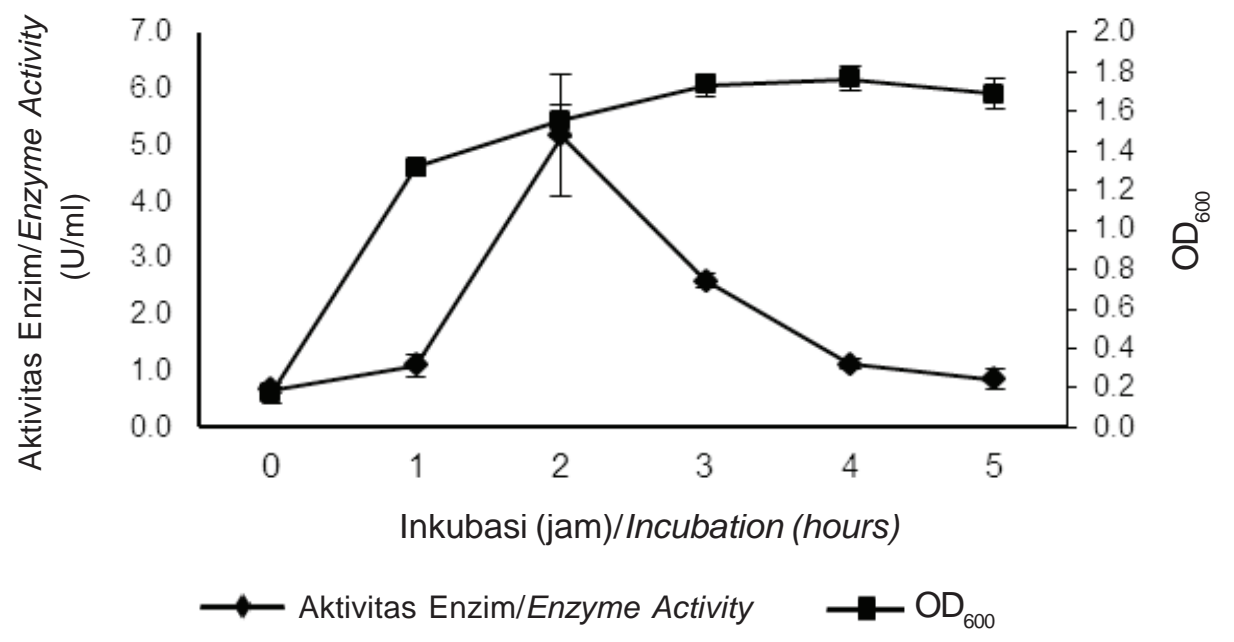

Gambar 5. Kurva pertumbuhan dan produksi enzim xilanase dari A. baumannii M-13.2A pada medium yang mengandung xilan.

Figure 5. Growth curve and xilanase production of A. baumannii M-13.2A from the medium containing of xilan.

\section{Karakterisasi enzim}

Xilanase $A$. baumannii M-13.2A memiliki suhu optimum $70^{\circ} \mathrm{C}$ dan relatif memiliki aktivitas yang cukup tinggi pada suhu $40-70^{\circ} \mathrm{C}$, namun turun secara signifikan pada suhu $80^{\circ} \mathrm{C}$ (Gambar 6). Enzim ini tergolong termoenzim, karena memiliki aktivitas optimum di dalam kisaran suhu $45-80^{\circ} \mathrm{C}$ (Nam et al., 2004).

Murray et al. (2003) menyatakan bahwa kemampuan aktivitas enzim termofilik pada suhu tinggi disebabkan oleh banyaknya ikatan disulfida pada struktur protein enzim. Ikatan disulfida (-S-S- atau sistin) merupakan ikatan kovalen yang sangat kuat sehingga dibutuhkan suhu yang sangat tinggi untuk mengurai ikatannya. Ikatan disulfida akan menstabilkan struktur sekunder dan struktur tersier protein enzim sehingga protein termoenzim tetap stabil pada suhu tinggi dan tidak kehilangan kemampuan katalisnya. Selain itu peningkatan suhu sampai pada suhu tertentu akan meningkatkan jumlah tumbukan antara sisi aktif enzim dengan substrat, sehingga kecepatan reaksi dan aktivitas enzim meningkat. Penurunan aktivitas enzim pada suhu yang lebih tinggi disebabkan oleh denaturasi pada suhu tinggi yang mengakibatkan putusnya ikatan hidrogen, ikatan hidrofobik dan ikatan elektrostatik pada enzim, sehingga merusak struktur lipatan protein 


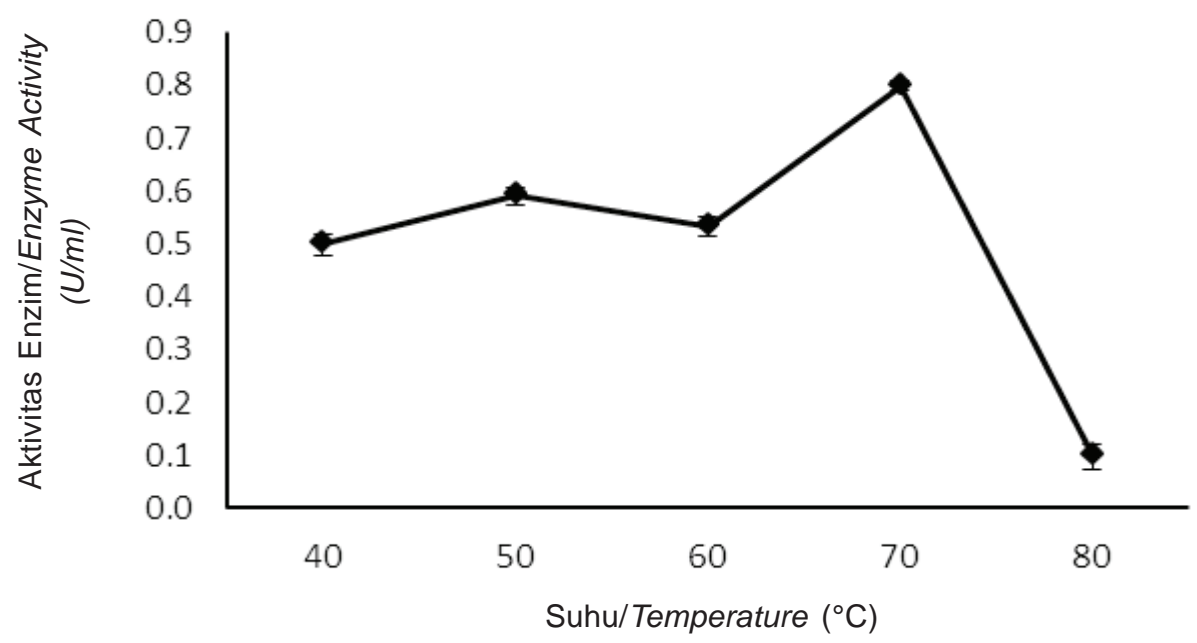

Gambar 6. Pengaruh suhu terhadap aktivitas enzim xilanase yang dihasilkan oleh A. baumannii M-13.2A. Figure 6. Effect of temperature on A. baumannii M-13.2A xilanase activity.

enzim (Lehninger 1995; Murray et al., 2003). Beberapa xilanase dari bakteri laut yang pernah dilaporkan adalah xilanase dari Geobacillus sp. MT-1 asal laut dalam Samudera Pasifik, bekerja optimum pada suhu $70^{\circ} \mathrm{C}$ (Wu et al., 2006); xilanase Bacillus sp. NCIM 59 , optimum pada suhu $70^{\circ} \mathrm{C}$ (Kulkarni \& Rao, 1996) dan xilanase dari Bacillus halodurans S7, optimum pada suhu $70^{\circ} \mathrm{C}$ (Mamo et al., 2006).

Pengaruh $\mathrm{pH}$ terhadap aktivitas enzim xilanase dapat dilihat pada Gambar 7. Tampak bahwa enzim bekerja optimum pada $\mathrm{pH}$ 8, sehingga bersifat alkalifilik. Aktivitas optimum xilanase yang dihasilkan oleh mikroba asal lingkungan laut umumnya pada kisaran pH 7-9 atau pada suasana netral-basa. Kulkarni \& Rao (1996) melaporkan bahwa Bacillus sp. NCIM 59 menghasilkan xilanase yang bekerja optimum pada pH 9. Xilanase Geobacillus sp. yang diisolasi dari laut dilaporkan memiliki aktivitas tertinggi pada pH 7 (Wu et al., 2006), sedangkan xilanase yang dihasilkan dari Bacillus halodurans $\mathrm{S} 7$ memiliki pH optimum 9 (Mamo et al., 2006). Jenis Bacillus lainnya dari perairan laut, yang menghasilkan xilanase ditemukan oleh Annamalai et al. (2009), yaitu Bacillus subtilis dengan xilanase yang dihasilkan memiliki aktivitas tertinggi pada pH 9, dan Menon et al. (2010), yaitu Bacillus pumilus strain GESF-1 dengan xilanase yang dihasilkan bekerja optimum pada $\mathrm{pH}$ 8. Enzim yang optimum pada $\mathrm{pH}$ lebih besar dari 7 atau lingkungan basa umumnya memiliki komposisi asam amino yang bersifat asam di bagian permukaan protein lebih tinggi, sehingga residu asam amino yang bermuatan negatif lebih tinggi (Dubnovitsky et al., 2005; Mamo et al., 2009; Zhao et al., 2011).

Permukaan protein yang kaya akan residu asam amino yang bersifat asam berperan penting dalam mempertahankan fungsi protein pada kondisi basa.

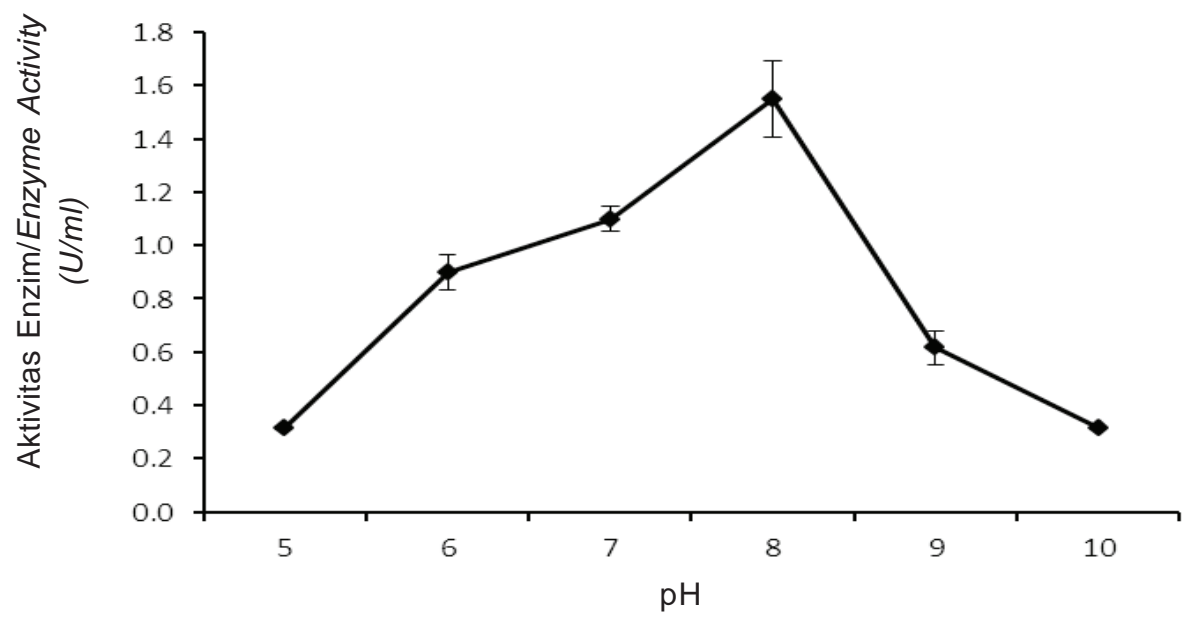

Gambar 7. Pengaruh pH terhadap aktivitas enzim xilanase yang dihasilkan oleh $A$. baumannii M-13.2A. Figure 7. Effect of $\mathrm{pH}$ on $\boldsymbol{A}$. baumannii M-13.2A xilanase activity. 


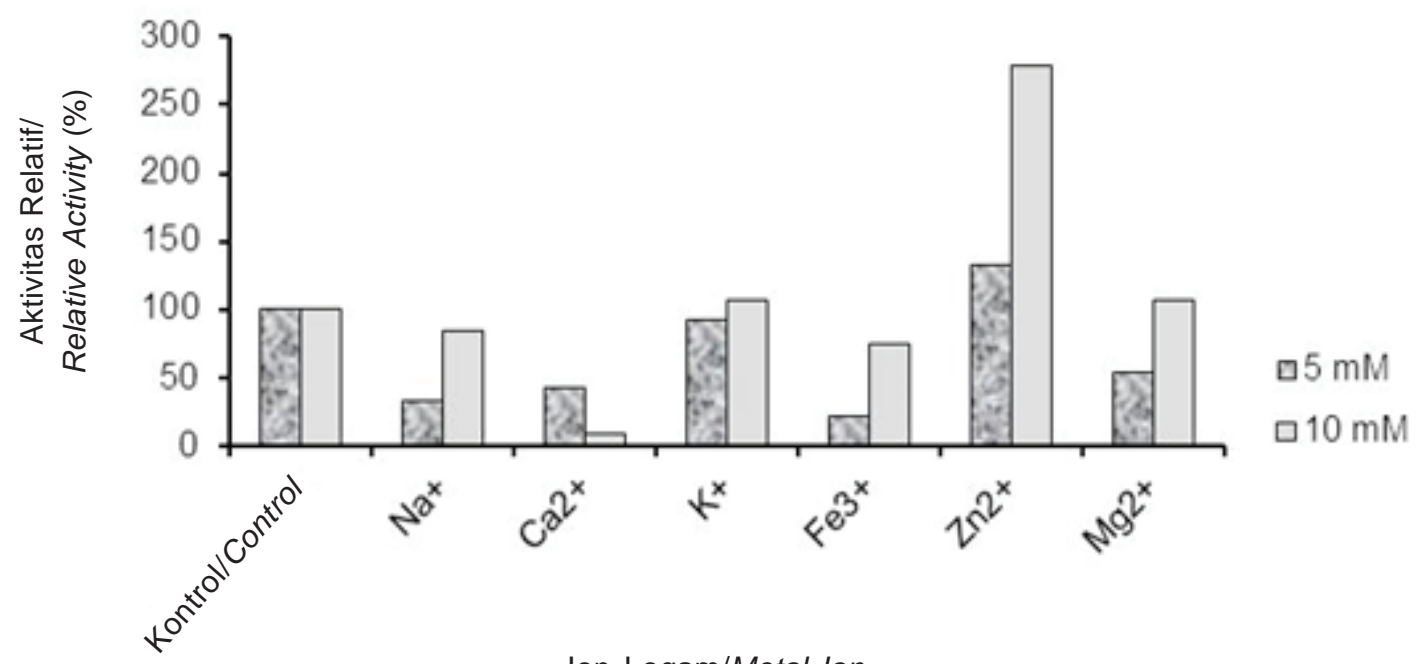

Ion Logam/Metal Ion

Gambar 8. Pengaruh ion logam terhadap aktivitas enzim xilanase yang dihasilkan oleh $\boldsymbol{A}$. baumannii M-13.2A.

Figure 8. Effect of metal ions on A. baumannii M-13.2A xilanase activity.

Biasanya, residu asam menunjukkan kemampuan mengikat air yang kuat dari molekul protein dalam kondisi terdeprotonasi pada $\mathrm{pH}$ tinggi. Adanya sejumlah karboksilat yang bermuatan negatif pada permukaan protein dapat menjaga protein dalam kondisi terhidrasi seluruhnya sehingga tidak terjadi agregasi. Zhao et al. (2011) lebih jauh menjelaskan bahwa aktivitas enzim yang optimum pada $\mathrm{pH}$ tinggi berkaitan dengan meningkatnya jumlah residu asam amino hidrofobik dan arginin serta menurunnya residu asam amino yang bersifat polar. Meningkatnya ikatan hidrogen menyebabkan konformasi protein enzim menjadi lebih kaku dan kompak sehingga lebih tahan terhadap denaturasi oleh alkali. Hal ini dinyatakan oleh mereka sebagai mekanisme adaptasi struktural berbagai protein terhadap lingkungan alkali. Enzim xilanase yang bekerja optimum dan stabil pada $\mathrm{pH}$ dan suhu tinggi sangat cocok untuk penggunaan pada industri pulp.

Pengaruh ion logam terhadap aktivitas enzim ditunjukkan pada Gambar 8. Penambahan ion $\mathrm{Zn}^{2+} 5$ $\mathrm{mM}$ dan $10 \mathrm{mM}$ dapat meningkatkan aktivitas hingga 133 dan 278\%. Hasil serupa dilaporkan oleh Meng et al. (2009) pada xilanase yang diproduksi oleh Demequina sp. JK4 dari perairan laut dalam. Namun demikian, ion $\mathrm{Zn}^{2+}$ dilaporkan bersifat sebagai inhibitor pada xilanase dari Geobacillus sp. MT-1 (Wu et al., 2006) dan xilanase dari Bacillus pumilus strain GESF1 (Menon et al., 2010). Ion $\mathrm{Fe}^{3+}, \mathrm{Ca}^{2+}$ dan $\mathrm{Mg}^{2+}$ pada konsentrasi $5 \mathrm{mM}$ memberikan pengaruh terhadap penurunan aktivitas enzim xilanase A.baumannii. Penghambatan aktivitas enzim akibat penambahan ion logam diduga karena ion logam tersebut mempengaruhi sisi aktif enzim xilanase sehingga struktur tiga dimensi enzim tidak sesuai dengan substrat. Hal ini berakibat pada ketidakmampuan substrat berikatan dengan sisi aktif enzim, sehingga reaksi berjalan lambat. Penghambatan aktivitas xilanase oleh ion $\mathrm{Fe}^{3+}$ juga dilaporkan oleh Menon et al. (2010) pada xilanase Bacillus pumilus strain GESF1, sedangkan Meng et al. (2009) menunjukkan pengaruh penghambatan ion $\mathrm{Ca}^{2+}$ pada xilanase dari Demequina sp. JK4 yang diisolasi dari perairan laut dalam.

\section{KESIMPULAN}

Isolat bakteri M-13.2A penghasil enzim xilanase, yang berasal dari perairan Manado, teridentifikasi sebagai Acinetobacter baumannii dengan kemiripan 99\%. Enzim ini apabila diproduksi dengan menggunakan media xilan broth pada kondisi suhu $30^{\circ} \mathrm{C}, 150 \mathrm{rpm}$ dengan starter yang mengandung total bakteri $(2,4-3,3) \times 10^{8} \mathrm{cfu} / \mathrm{mL}$ atau nilai $\mathrm{OD}_{600} 0,715$ sebanyak 10\% memerlukan waktu 2 hari. Enzim xilanase yang dihasilkan bekerja optimum pada $\mathrm{pH} 8$ dan suhu $70^{\circ} \mathrm{C}$, namun masih memiliki aktivitas yang cukup tinggi pada kisaran suhu $40-70^{\circ} \mathrm{C}$. Penambahan ion $\mathrm{Zn}^{2+}$ dapat meningkatkan aktivitas enzim, sebaliknya ion $\mathrm{Ca}^{2+}$ dan $\mathrm{Fe}^{3+}$ menurunkan aktivitas enzim. Informasi lebih lengkap diperlukan untuk dapat memberikan alternatif aplikasi enzim ini, diantaranya terkait dengan stabilitas panas, stabilitas $\mathrm{pH}$, spesifisitas substrat dan pemurniannya. 


\section{DAFTAR PUSTAKA}

Annamalai, N., Thavasi, R., Jayalakshmi, S., and Balasubramanian, T. 2009. Thermostable and alkaline tolerant xylanase production by Bacillus subtilis isolated from marine environment. Indian Journal of Biotechnology. 8: 291-297.

Araki, T., Tani, S., Maeda, K., Hashikawa, S., Nakagawa, H., and Morishita, T. 1999. Purification and characterization of â-1,3-xylanase from a marine bacterium, Vibrio sp. XY-214. Bioscence Biotechnology Biochemistry. 63(11): 2017-2019.

BCC Research. 2011. Enzymes in industrial applications: Global markets. Report highlights. http:// www.bccresearch.com/market-research/ biotechnology/enzymes-industrial-applicationsbio030f.html Diakses pada bulan Mei 2013.

Benson. 2001. Microbiologycal Applications Lab Manual. 8th ed. The McGraw Hill Companies, Inc., New York

Bergogne-Berezin, E. and Towner, K.J. 1996. Acinetobacter spp. as nosocomial pathogens: microbiological, clinical, and epidemiological features. Clin Microbiol Rev. (9): 148-65.

Biely, P. 2003. Hand Book of Food Enzymology. Chapter 71. Xylanolitic enzyme. Marcel Dekker,Inc. New York: $37 \mathrm{pp}$.

Bouvet, P.J.M. and Grimont, P.A.D. 1987. Identification and biotyping of clinical isolates of Acinetobacter. Ann. Inst. Pasteur Microbiol. 138: 569--578.

Brock, T.D., Madigan, M.T., Martinko, J.M., and Parker, J., 1994. Biology of Microorganism. $7^{\text {th }}$ ed. Prentice Hall, Inc. New Jersey.

Constantiniu, S., Romaniuc, A., Iancu, L.S., Filimon, R., and Tarai,J. 2004. Cultural and biochemical characteristics of Acinetobacter spp. Strains isolated from hospital units. The Journal of Preventive Medicine. 12 (3-4): 35-42.

Degue, A. 2013. The many uses of xilanase : industrial applications. http://www.exp/orecuriocity.org/ Content.aspx?ContentID=2399. Diakses pada bulan September 2013.

Dubnovitsky, A.P., Kapetaniou, E.G., and Papageorgiou A.C. 2005. Enzyme adaptation to alkaline pH: Atomic resolution (1.08A) structure of phosphoserine aminotransferase from Bacillus alcalophilus. Protein Science. 14: 97-110.

Freedonia. 2011. World enzymes industry. http:// www.reportlinker.com/p0747897-summary/WorldEnzymes-Industry.html. Diakses pada bulan Maret 2013.

Gandjar, I., Koentjoro, I.R., Mangunwardoyo, W., dan Soebagya, L.1992. Pedoman Praktikum Mikrobiologi Dasar. Jurusan Biologi FMIPA UI, Depok.

Holt, J.G., Krieg, N.R., Sneath, P.H.A., Staley, J.T., and Williams, S.T. 1994. Bergey's Manual of Determinative Bacteriology. $9^{\text {th }}$ ed. Williams and Wilkins. Baltimore, USA. 787 p.

Hung, K.S., Liu, S.M., Tzou, W.S., Lin, F.P., Pan, C.L., Fang, T.Y., Sun, K.H., and Tang, S.J. 2011. Characterization of a novel $\mathrm{GH} 10$ thermostable, halophilic xylanase from the marine bacterium Thermoanaerobacteriumsaccharolyticum NTOU1. Process Biochemistry. 46(6): 1257-1263.

Jiang, Z., Cong, Q., Yan, Q., Kumar, N., and X. Du. 2010. Characterisation of a thermostable xylanase from Chaetomium sp. and its application in Chinese steamed bread. Food Chemistry. 120: 457-462.

Khandeparker, R., Verma, P., and Deobagkar, D. 2011. A novel halotolerant xylanase from marine isolate Bacillus subtilis cho40: gene cloning and sequencing. New Biotechnology. 6(28): 814-821.

Kulkarni, N. and Rao, M. 1996. Application of xylanase from alkaliphilic thermophilic Bacillus sp. NCIM 59 in biobleaching of bagasse pulp. Journal of Biotechnology. (51): 167-173.

Kulkarni, N., Lakshmikumaran, M., and Rao, M. 1999. Xylanase II from an alkaliphilic thermophilic Bacillus with a distinctly different structure from other xylanases: Evolutionary relationship to alkaliphilic xylanases. Biochem Biophys Res Commun. 263(3): 640-645.

Lehninger, A.L. 1995. Biochemistry the Molecular Basis of Cell Structure and Function. 2nd ed. Worth Publishers. Inc., New York. 1104 p.

Li, X., She, Y., Sun, B., Song, H., Zhu, Y., Lv, Y., and Song, H. 2010. Purification and characterization of a cellulase-free, thermostable xylanase from Streptomyces rameus L2001 and its biobleaching effect on wheat straw pulp. Biochemical Engineering. 52: 71-78.

Mamo, G., Thunnissen, M., Hatti-Kaul, R., and Mattiasson, B. 2009. An alkaline active xylanase: insights into mechanisms of high $\mathrm{pH}$ catalytic adaptation. Biochimie.91(9):1187-96.doi:10.1016/ j.biochi.2009.06.017

Mamo, G., Kaul, R.H., and Mattiasson, B. 2006. A thermostable alkaline active endo-â-1-4 xylanase from Bacillus halodurans S7: purification and characterization. Enzyme and Microbial Technology. (39): 1492-1498.

Marchesi, J.R., Sato, T., Weightman, A.J., Martin, T.A., Fry, J.C., Hiom, S.J. and Wade, W.G. 1998. Design and evaluation of useful bacterium-specific PCR primers that amplify genes coding for bacterial 16S rRNA. Appl. Environm. Microbiol. 64: 795-799.

Meng, X., Shao, Z., Hong, Y., Lin, L., Li, C., and Liu, Z. 2009. A novel $\mathrm{pH}$-stable, bifunctional xylanase isolated from a deep-sea microorganism, Demequina sp. JK4. Journal of microbiology and biotechnology. 19(10): 1077-1084.

Menon, G., Mody, K., Keshri, J., and Jha, B. 2010. Isolation, purification and characterization of haloalkaline xilanase from a marine Bacillus pumilus strain GESF1. Biotechnology and Bioprocess Engineering. 6(15): 998-1005.

Munifah, I., Chasanah, E., dan Pratitis, A. 2009. Isolasi dan Produksi Enzim Xilanase dari Mikroba Laut. Laporan akhir Hibah Penelitian Bagi Peneliti dan Perekayasa Departemen Kelautan dan Perikanan. Balai Besar Riset Pengolahan Produk dan Bioteknologi Kelautan dan Perikanan. 
Murray, R.K., Granner, D.K., Mayes, P.A., and Rodwell, V.W. 2003. Biokimia Harper. Terj. Harper's biochemistry. Penerbit buku kedokteran EGC, Jakarta. $1 x+891$ pp.

Nam, E.S. 2004. Â-galactosidase gene of Thermus thermophulus KNOUC11 isolated from hot springs of a volcanie area in New Zealand identification of the bacteria cloning and expression of the gene in Escherchia coli. Asian-Aus Journal Animal Science. 17: 1591-1598.

Nurhayati, T., Suhartono, M.T., Desniar, dan Suwardinni, R. 2006. Pengaruh variasi $\mathrm{pH}$ dan $\mathrm{NaCl}$ terhadap produksi inhibitor protease yang dihasilkan oleh Acinetobacter baumannii (bakteri yang berasosiasi dengan spons Plakortis nigra. Buletin Teknologi Hasil Perikanan IX. (2): 56-69.

Peleg, A.Y., Seifert, H., and Paterson, D.L. 2008. Acinetobacter baumannii: emergence of a successful pathogen. Clin. Microbiol. Rev. 21538582.

Polizeli, M.L.T.M., Rizzatti, A.C.S, Monti, R., Terenzi, H.F., Jorge, J.A., and Amorim, D.S. 2005. Xylanases from fungi: properties and industrial applications. MiniReview. Appl Microbiol Biotechnol. 67: 577-591. doi: 10.1007/s00253-005-1904-7.
Retnoningrum, D.S. 2009. Extracellular products of Streptococcus pyogenes and their involvement in pathogenesis. Jurnal Matematika dan Sains. 14(2): 33-40.

Richana, N. 2002. Produksi dan prospek enzim xilanase dalam pengembangan bioindustri di Indonesia. Buletin AgroBio. 5(1): 29-36

Saleem, M., Tabassum, M.R., Yasmin, R., and Imran, M. 2009. Potential of xylanase from thermophilic Bacillus sp. XTR-10 in biobleaching of wood kraft pulp. International Biodeterioration and Biodegradation (63): 1191-1124.

Wu, S., Liu, B., and Zhang, X. 2006. Characterization of a recombinant thermostable xylanase from deep-sea thermophilic Geobacillus sp. MT-1 in East Pacific. Applied Microbiology and Biotechnology. 6(72): 1210-1216.

Zhao, Y., Zhang, Y., Cao, Y., Qi, J., Mao, L., Xue, Y., Gao, F. Peng, H., Wang, X., Gao, G.F. and Ma, Y. 2011. Structural analysis of alkaline $\beta$-mannanase from alkaliphilic Bacillus sp. N16-5: Implications for adaptation to alkaline conditions. Journal List PLoS One. 6(1); e14608. doi: 10.1371/journal.pone. 0014608. PMCID : 3059134. 